\title{
Understanding genetic diversity, spatial genetic structure, and mating system through microsatellite markers for the conservation and sustainable use of Acrocomia aculeata (Jacq.) Lodd. Ex Mart.
}

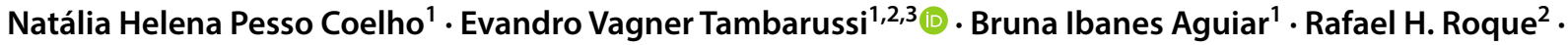 \\ Renan Marcelo Portela ${ }^{2}$ - Rayssa Chaves Braga ${ }^{2}$ - Daniela Sanson ${ }^{2} \cdot$ Richeliel A. R. Silva $^{2}$ - Elza Martins Ferraz ${ }^{1}$. \\ Maria Andréia Moreno ${ }^{1} \cdot$ Paulo Y. Kageyama ${ }^{1}$. Flávio Bertin Gandara ${ }^{1}$
}

Received: 1 November 2017 / Accepted: 14 March 2018 / Published online: 19 March 2018

(c) Springer Science+Business Media B.V., part of Springer Nature 2018

\begin{abstract}
Acrocomia aculeata is a native palm distributed widely throughout Brazil that is used in a diverse array of products from the food industry to biodiesel oil production. This study uses nine microsatellite loci to assess the genetic diversity, spatial genetic structure (SGS), and mating system of A. aculeata. A total of 200 samples were collected from four populations (Fusquinha-FU, Padre Josimo-PJ, Gleba XV-GB, and Amparo-AM), in São Paulo State, Brazil. We also collected fruits from 20 randomly selected seed trees in the FU population to assess mating patterns, for a total of 246 genotyped embryos. We identified a total of 103 alleles and all loci were polymorphic. The average observed heterozygosity $\left(H_{o}\right)$ ranged from $0.410(\mathrm{AM})$ to $0.531(\mathrm{FU})$ and expected heterozygosity $\left(H_{e}\right)$ ranged from $0.547(\mathrm{PJ})$ to $0.615(\mathrm{~GB})$. The average fixation index $(F)$ ranged from 0.043 to 0.254 for $\mathrm{FU}$ and AM populations, respectively. The coancestry coefficient $\left(\theta_{x y}\right)$ was significant up to $38 \mathrm{~m}$ in PJ the population and $71 \mathrm{~m}$ in AM. Individual palm outcrossing rates were predominantly high $\left(t_{m}=0.985\right)$ and the paternity correlation $\left(r_{p_{(m)}}=0.02\right)$ was significantly low, indicating a high probability of the occurrence of half-sibs. Compared to other palm species, the studied populations show high levels of genetic diversity. Our results confirm that $A$. aculeata is primarily allogamous, with no significant paternity correlation, and seeds should be harvested from at least 40 trees to ensure high levels of genetic diversity in seed collection programs.
\end{abstract}

Keywords Brazilian Atlantic forest $\cdot$ Conservation genetics $\cdot$ Microsatellite markers $\cdot$ Population genetics $\cdot$ Tropical palm species

\section{Introduction}

Natália Helena Pesso Coelho and Evandro Vagner Tambarussi have contributed equally to this work.

Paulo Y. Kageyama-In memoriam

Evandro Vagner Tambarussi

tambarussi@gmail.com

1 Escola Superior de Agricultura "Luiz de Queiroz", University of São Paulo, Av. Padua Dias, 11, PO Box 9, Piracicaba, SP 13418-900, Brazil

2 Universidade Estadual do Centro-Oeste, PR 153, Km 7, Riozinho, Irati, PR 84500-000, Brazil

3 Programa de Pós-Graduação em Ciência Florestal FCA/UNESP - Rua José Barbosa de Barros, 1780, Portaria II: Rodovia Alcides Soares, Km 3, Botucatu, SP 18610-307, Brazil
Around the world, natural forests have been deforested extensively due to agriculture, silviculture, and urban development, resulting in spatially isolated fragments or individuals scattered across landscapes (Lander et al. 2010). Global forest loss is estimated at 9.4 million hectares per year, of which 2.3 million are lost from the humid forests of Brazil (Ribeiro et al. 2011). In the past, the Atlantic Forest Biome covered a vast amount of Brazilian territory; however, the biome continues to suffer significant deforestation (Ribeiro et al. 2011), and only $12.5 \%$ of the original area remains (INPE 2015). In São Paulo State, only $15.6 \%$ of the original Atlantic Forest cover is left, and these isolated fragments are threatened by anthropogenic activities. The extreme west of São Paulo State, known as Pontal do Paranapanema, is 
one of the most devastated regions in the State due to land conversion and human occupation (Leite 1999; Ditt 2002). According to the Forest Institute of São Paulo, only 8.5\% of the native vegetation remains in the region today (SIFESP 2009). The region also has the second worst Human Development Index (HDI) in the State and has been affected by social conflict over land ownership and occupation that occurred in the 1980s, leading to the settlement of approximately 6000 families (Leite 1999).

Human intervention has a destabilizing effect on natural ecosystems by disturbing their dynamic equilibrium. Forest fragmentation reduces the size of populations and increases the distance between populations; these processes result in the loss of alleles, reduced heterozygosity, and reproductively isolated populations, thereby reducing gene flow, increasing inbreeding and genetic differentiation between populations, and reducing effective population size (Kageyama et al. 2003; Tambarussi et al. 2016). The main consequence of inbreeding is inbreeding depression, leading to decreased productivity (Charlesworth and Charlesworth 1999; Tambarussi et al. 2017).

Acrocomia aculeata (Jacq.) Lood. Ex Mart. is a perennial, tropical forest, palm tree species with a wide distribution throughout Central and South America. In Brazil, it occurs mainly in the states of Bahia, Ceará, São Paulo, Minas Gerais, Mato Grosso, and Mato Grosso do Sul (Leitman et al. 2015). The species occurs at high densities in abandoned pastures, where it can develop into a dominant tree species forming spontaneous clusters (Scariot et al. 1991, 1995). The species can reach up to $15 \mathrm{~m}$ in height and is characterized by spines on the stems, leaves, and petioles. The leaves are pinnate and spread across multiple planes. The species is monoecious, and beetle and wind-pollinated. Inflorescences consist of female flowers at the base and male flowers toward the top of the structure. It is a protogynous species and it blooms from October to December. The fruit is a yellow drupe that matures from September to January (Scariot et al. 1991). In São Paulo State, and particularly in the Pontal do Paranapanema region, the species occurs in large clusters in rural settlements, and its economic potential is increasing, especially for biodiesel. A better understanding of the species could help to improve the management of natural populations and their use in agroforestry systems, thus stimulating socio-economic development in the region and benefitting local rural families.

Previous studies have described the genetic diversity and mating system of the A. aculeata. Oliveira et al. (2012), studying five A. aculeata populations, showed high levels of genetic diversity within populations. According to Abreu et al. (2012), the species is self-compatible and presents a mixed mating system with a predominance of outcrossing. Lanes et al. (2016) studied the genetic diversity and mating system in two developmental stages of A.aculeata and observed high levels of genetic diversity in adults and juveniles, as well as a low observed heterozygosity and high positive fixation index, suggesting endogamy and selection against homozygotes. Their study further indicates that the A. aculeata mating system is primarily outcrossing (allogamous). However, genetic information about the overexploited populations of A. aculeata that occur in Pontal do Paranapanema are lacking despite the fact that there are thousands of hectares of clustered populations of this species, interspersed among a vast array of rural settlements, that could be used as a sustainable resource. Therefore, the evaluation of the genetic variation among and within these natural populations, and a more in depth understanding of its mating system, can inform strategies for its use in management plans, conservation projects, and genetic improvement of the species without compromising the species' genetic diversity.

Thus, the current study was carried out in Legal Reserves (areas protected by Brazilian law for the preservation and conservation of biodiversity within rural properties that can be used sustainably) of rural settlements focusing on subpopulations ranging in size from 150 to 480 ha and a 3 ha private property, all of which are located in São Paulo State, Brazil. Specifically, we investigate the genetic diversity and intrapopulation spatial genetic structure (SGS) in four A. aculeata populations and the mating system in one population.

\section{Materials and methods}

\section{Study sites and sampling}

The four natural A. aculeata populations used in this study include three populations located in rural settlements in Pontal do Paranapanema (Fusquinha-FU, Gleba XV de novembro-GB, and Padre Josimo-PJ) and one in a privatelyowned area in the municipality of Amparo (AM), Sao Paulo State, Brazil. The FU and PJ populations are located in the municipality of Teodoro Sampaio, and GB population is located in the municipality of Rosana. FU has a total area of 1081.77 ha and 46 families live in the settlement. PJ has a total area of 2290.19 ha and 96 families live in the settlement. GB has a total area of 13,309.76 ha with 571 families. The AM population is unpopulated and has a total area of 3.0 ha (Fig. 1). In the four study sites, A. aculeata occurs as aggregate clusters with a high density of individuals per hectare (on average $300 \mathrm{palms} \mathrm{ha}^{-1}$, personal observation) forming continuous forests of the species.

From each population, we sampled and GPS georeferenced (Garmin: GPSMAP 76CXS) 50 reproductive $A$. aculeata individuals for a total of 200 samples. For genetic 


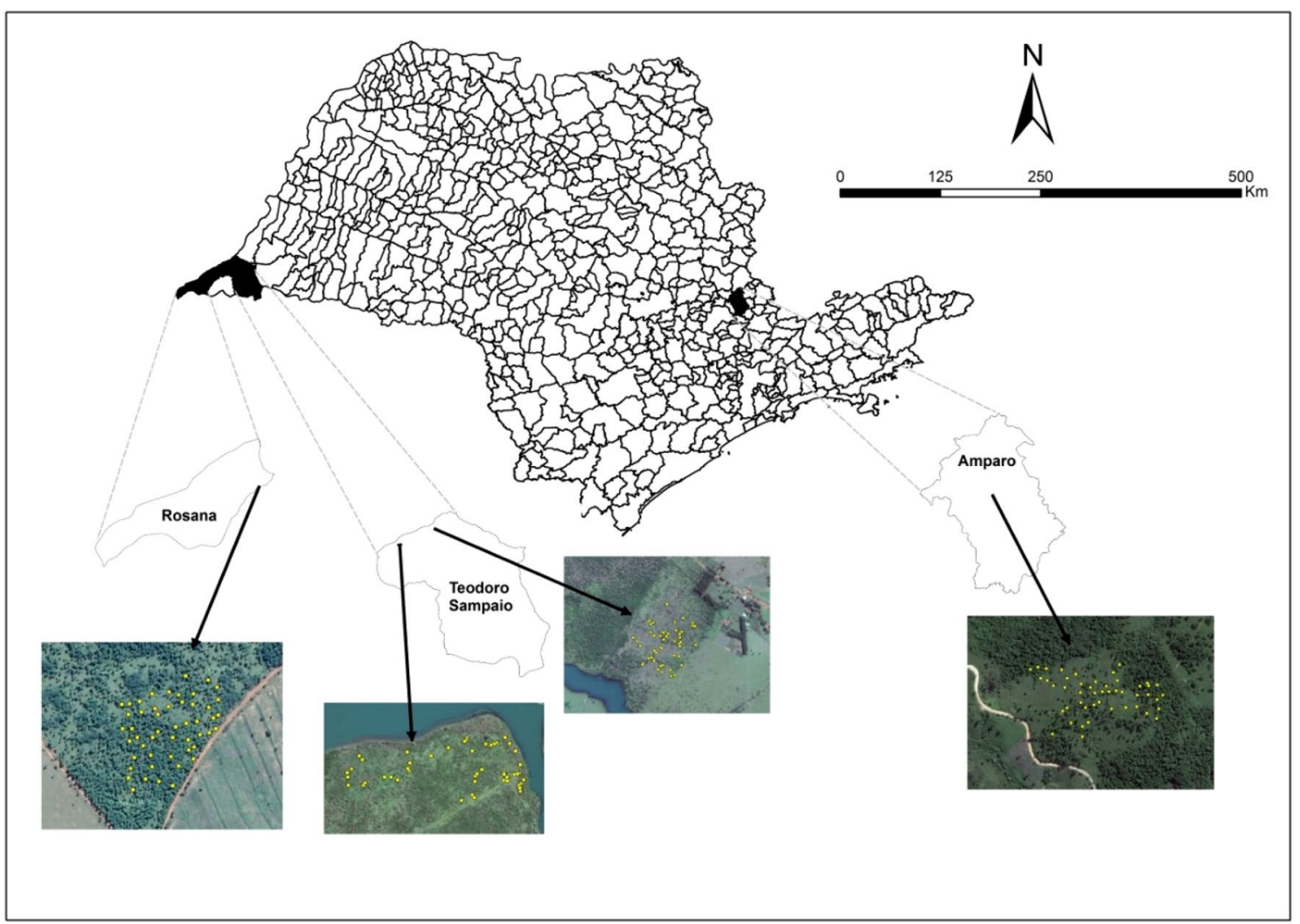

Fig. 1 Location of Acrocomia aculeata sample populations, three in Pontal do Paranapanema (FU, PJ, and GB) and one in Amparo (AM), São Paulo State, Brazil. The spatial distribution of the collected genotypes are indicated by yellow dots. (Color figure online)

analyses, leaf samples were collected, stored in containers with silica gel, and transported to the laboratory.

To study the mating system at the population level, 600 fruits were harvested directly from the canopy of 20 randomly selected seed trees in the FU population in August 2015. After harvesting, the fruits were packed in polystyrene boxes and transported to the laboratory. The fruits were kept refrigerated until in vitro inoculation. The in vitro procedure was necessary due to previous difficulties in seed germination. Seeds were removed from fruits and then the embryo was removed from the seeds and disinfected. For disinfection, we placed the embryos in $2.5 \%$ chlorine for $5 \mathrm{~min}$ and then rinsed with distilled and sterilized water. The embryos were subsequently inoculated in MS medium (Murashige and Skoog 1962), supplemented with $30 \mathrm{~g} \mathrm{~L}^{-1}$ of sucrose, adjusted to $\mathrm{pH} 5.8$, and then semi-solidified with $2.3 \mathrm{~g} \mathrm{~L}^{-1}$ of Phytagel ${ }^{\mathrm{TM}}$. The culture medium was placed in $300 \mathrm{~mL}$ flasks with $50 \mathrm{~mL}$ of medium, which were then autoclaved for $20 \mathrm{~min}$ at $121^{\circ} \mathrm{C}$ with $1 \mathrm{kgf} \mathrm{cm}^{-2}$ pressure. Embryo germination was carried out under light conditions, with a temperature of $25 \pm 2{ }^{\circ} \mathrm{C}$, irradiance of $23 \mu \mathrm{mol} \mathrm{m}^{-2} \mathrm{~s}^{-1}$, and a $16 \mathrm{~h}$ photoperiod using cool white fluorescent bulbs (General Electric ${ }^{\circledR} 40 \mathrm{w}$ Super daylight). A total of 600 embryos were inoculated and separated by seed tree. After seed germination, 246 embryos were genotyped. The number of genotyped progeny ranged from three to 22 per seed tree.

\section{DNA extraction and microsatellite genotyping}

Genomic DNA extraction was performed using CTAB (Doyle and Doyle 1990), with PVP 40 2\% and mercaptoethanol 3\%. After extraction, electrophoresis amplification reactions and fragment analysis were performed using the same criteria as described in Da Silva et al. (2016). We used nine microsatellite loci: four developed and described by Nucci et al. (2008)-Aacu30, Aacu26, Aacu07, Aacu12; and five unpublished markers-MAC245, MAC115, MAC201, MAC240, MAC23 (M. Moretzsohn, Embrapa, unpublished).

\section{Analyses of linkage disequilibrium, genetic diversity, genetic differentiation and structure}

Linkage disequilibrium between pairs of loci were tested to verify the allelic association of different loci. We assessed statistical significance using Monte Carlo permutations of alleles among individuals, followed by a Bonferroni correction $(\alpha=0.05)$. Allelic frequencies and intrapopulation genetic diversity were assessed for adult individuals 
using the means of number of alleles per locus $(A)$, and observed $\left(H_{o}\right)$ and expected heterozygosity $\left(H_{e}\right)$ according to Hardy-Weinberg equilibrium $\left(\widehat{H}_{e}=1-\sum p_{i}^{2}\right)$. The statistical significance was tested using the permutation method (1000 replicates). We performed all estimates using the FSTAT program (Goudet 2001). The $F$ statistics $\left(F_{I S}, F_{I T}\right.$ and $F_{S T}$ ) were used as a parameter of genetic differentiation between and within subpopulations (Wright 1951). We used the program Micro-Checker 2.2.3 to estimate the frequencies of null alleles for each locus (Van Oosterhout et al. 2006) and the Structure software (Pritchard et al. 2000) to estimate the most probable number of clusters in the sampled populations. Fifteen independent simulations were performed for each value of $K$ (from one to eight). For each simulation, we used 1,000,000 iterations of MCMC with an initial disposal (burn-in) of 250,000. We used the mixed ancestry and correlated allelic frequency models. The number of $K$ was determined according to the $\Delta K$ criteria proposed by Evanno et al. (2005).

\section{Mating system analysis}

Mating system analysis was based on the mixed mating and correlated mating models implemented in the MLTR program (Ritland 2002). The analyses were estimated at the population level and for each seed tree for the FU population. The numerical method used was the Expectation Maximization (EM) maximum likelihood for seed trees and Newton-Raphson at the population level.

The estimated parameters were: multilocus outcrossing rate $\left(t_{m}\right)$; single-locus outcrossing rate $\left(t_{s}\right)$; outcrossing rate among relatives $\left(t_{m}-t_{s}\right)$; multilocus correlation of selfing $\left(r_{s}\right)$; and multilocus paternity correlation $\left(r_{p(m)}\right)$. The estimates of the $95 \%$ confidence interval $(95 \% \mathrm{CI})$ at the population level were obtained using 1000 re-sampling bootstraps, with progeny as the unit of resampling. To estimate the standard error at the progeny level, the unit of resampling was also individuals within progenies. These parameters were used to estimate other genetic and demographic parameters, including effective number of pollen donors $\left(\widehat{N}_{e p}=1 / \widehat{r}_{p(m)}\right)$ and average coancestry coefficient within progenies: $\bar{\theta}=0.125\left(1+\widehat{F}_{p}\right)\left[4 \widehat{s}+\left(\hat{t}_{m}+\widehat{s}_{m} \widehat{r}_{s}\right)\left(1+\widehat{r}_{p(m)}\right)\right]$, where $F_{p}$ is the parental inbreeding coefficient (Ritland 1989).

The frequency of pairwise self-sibs $\left(P_{S S}\right)$, half-sibs $\left(P_{H S}\right)$, full-sibs $\left(P_{F S}\right)$, and self-half-sibs $\left(P_{S H S}\right)$ within progenies were estimated as: $P_{S S}=s^{2}, P_{H S}=t_{H S}^{2}\left(1-r_{p(m)}\right)$, $P_{F S}=t_{m}^{2} r_{p(m)}$, and $P_{s h s}=2 s t_{m}$, respectively (Sebbenn 2006). The effective size within progeny was estimated as described by Tambarussi et al. (2016).

We estimated the number of seed trees necessary for seed collection using a reference effective size of 150 (Lacerda et al. 2008) in the total progeny array: $\hat{m}=N_{e(\text { reference })} / \widehat{N}_{e(v)}$
(Sebbenn 2003). This estimate is based on three assumptions: (i) the seed trees are not related; (ii) the seed trees do not have an overlapping pollen pool (i.e., each seed tree mated with a different set of pollen donors); and (iii) the selected seed trees did not mate with each other. Thus, related individuals in the progeny array will occur only within progeny but not among different sampled progeny.

\section{Spatial genetic structure}

We analyzed the intrapopulation SGS in adult trees of all populations using the software SPAGEDI version 1.3 (Hardy and Vekemans 2002). The mean multilocus coancestry coefficient $\theta_{x y}$ was calculated for 10 different distance classes for each population, using the estimator described by Loiselle et al. (1995). The number of pairs of individuals ranged from 121 to 124 within each distance class. To test whether the mean values were significantly different from zero, a confidence interval of $95 \%$ probability was estimated for each value observed in any distance class, using 1000 permutations per individual between different distance classes; from this, the correlogram was constructed for each population.

\section{Results}

\section{Linkage disequilibrium, genetic diversity, genetic differentiation and structure}

Our analysis of linkage equilibrium after Bonferroni correction $(\alpha=0.05)$, showed five pairs of loci (MAC245xMAC202; MAC115xMAC201; MAC115xMAC240; MAC201xMAC240; and MAC201xMAC23) with a low degree of linkage disequilibrium (3.48\%). Because this linkage was only observed in AM population, we assumed that there is no linkage between loci. High levels of polymorphism were detected in all A. aculeata populations, with a total of 103 identified alleles. Considering all analyzed loci, the population with the greatest number of alleles was GB with 67 alleles, followed by AM with 59, PJ with 58, and FU with 56 alleles (Table 1).

We found 76 rare alleles distributed across the four studied populations, with 14, 20,18, and 24, rare alleles in FU, $\mathrm{PJ}, \mathrm{GB}$, and AM populations, respectively. Of the 76 rare alleles, 34 were rare and private $\left(A_{r p}\right)$ and were identified in all populations: $\mathrm{FU}=8 ; \mathrm{PJ}=7 ; \mathrm{GB}=11$; and $\mathrm{AM}=8$. Only three common and private alleles were found in GB (1) and $\mathrm{AM}$ (2), while FU and PJ populations did not present this type of allele (Table 1).

Considering all populations, the number of alleles per locus $(A)$ varied from 2 to 15 , with an average of 6.2 , 6.4, 7.4, and 6.5 for FU, PJ, GB, and AM populations, 
Table 1 Microsatellite loci analyzed for Acrocomia aculeata in the populations Fusquinha (FU), Padre Josimo (PJ), Gleba XV (GB), and Amparo (AM), São Paulo State, Brazil

\begin{tabular}{|c|c|c|c|c|c|c|c|c|c|c|c|c|c|c|c|}
\hline \multirow[t]{3}{*}{ Locus } & \multirow[t]{3}{*}{$A_{T}$} & \multicolumn{14}{|c|}{ Populations } \\
\hline & & \multicolumn{3}{|c|}{ FU } & \multicolumn{3}{|l|}{ PJ } & \multicolumn{4}{|l|}{ GB } & \multicolumn{4}{|c|}{$\mathrm{AM}$} \\
\hline & & $A$ & $A_{r}$ & $A_{r p}$ & $A$ & $A_{r}$ & $A_{r p}$ & A & $A_{r}$ & $A_{r p}$ & $A_{p}$ & A & $A_{r}$ & $A_{r p}$ & $A_{p}$ \\
\hline Aacu30 & 7 & 4 & 1 & 0 & 4 & 2 & 0 & 6 & 1 & 0 & 1 & 4 & 1 & 0 & 0 \\
\hline Aacu26 & 9 & 4 & 1 & 0 & 5 & 0 & 1 & 6 & 2 & 1 & 0 & 5 & 1 & 0 & 1 \\
\hline Aacu07 & 4 & 2 & 0 & 0 & 3 & 1 & 1 & 2 & 1 & 0 & 0 & 2 & 1 & 0 & 1 \\
\hline Aacu12 & 19 & 11 & 5 & 2 & 10 & 3 & 2 & 11 & 2 & 4 & 0 & 6 & 1 & 2 & 0 \\
\hline MAC245 & 17 & 7 & 1 & 0 & 8 & 3 & 0 & 12 & 4 & 1 & 0 & 15 & 5 & 4 & 0 \\
\hline MAC115 & 12 & 5 & 3 & 0 & 7 & 3 & 1 & 8 & 2 & 1 & 0 & 8 & 4 & 0 & 0 \\
\hline MAC201 & 8 & 5 & 1 & 1 & 7 & 2 & 2 & 5 & 2 & 0 & 0 & 3 & 1 & 0 & 0 \\
\hline MAC240 & 18 & 10 & 1 & 2 & 8 & 3 & 0 & 13 & 4 & 3 & 0 & 11 & 8 & 0 & 0 \\
\hline MAC23 & 9 & 8 & 1 & 3 & 6 & 3 & 0 & 4 & 0 & 0 & 0 & 5 & 2 & 0 & 0 \\
\hline Total & 103 & 56 & 14 & 8 & 58 & 20 & 7 & 67 & 18 & 10 & 1 & 59 & 24 & 6 & 2 \\
\hline
\end{tabular}

Total number of alleles per locus for entire sample $\left(A_{T}\right)$, number alleles per locus within each population $(A)$, rare alleles $\left(A_{r}\right)$, rare and private alleles $\left(A_{r p}\right)$, and private alleles $\left(A_{p}\right)$ respectively. The average values for $H_{o}$ were $0.531,0.482$, 0.508 , and 0.410 for FU, PJ, GB, and AM, respectively. The average for $H_{e}$ were $0.554,0.547,0.615$, and 0.567 for FU, $\mathrm{PJ}, \mathrm{GB}$, and AM, respectively. The GB population presented an $H_{e}$ higher than $H_{o}$ for almost all loci, except for Aacu07, for which the values were equal $\left(H_{o}=H_{e}=0.020\right)$, and MAC23 which showed almost equal values $\left(H_{o}=0.700\right.$ and $\left.H_{e}=0.696\right)$. We found a positive and significant mean fixation index $(F)$ in the $\mathrm{PJ}(0.127), \mathrm{GB}(0.170)$, and $\mathrm{AM}(0.254)$ populations. The presence of null alleles was detected in three loci for PJ, GB, and AM populations. For the FU population, we did not detect null alleles and the mean fixation index was 0.043, while loci Aacu30, Aacu07, Aacu12, and MAC240 presented a negative fixation index, suggesting an excess of heterozygotes (Table 2).

The values for Wright statistics were $0.144,0.168$, and 0.288 for $F_{I S}, F_{S T}$, and $F_{I T}$, respectively. The results show genetic differentiation of $16.8 \%$ among the populations, meaning that $83.2 \%$ of diversity is distributed within populations (data not shown).

The STRUCTURE analysis revealed that the most probable number of real populations was two $(K=2)$. The two clusters coincided with the two regions included in the study, one in Pontal do Paranapanema (FU, PJ, and GB) and other in Amparo (AM) (Fig. 2).

\section{Mating system}

Estimates at the population level showed the following results: multilocus outcrossing rate $\left(t_{m}=0.985\right)$; single locus outcrossing rate $\left(t_{s}=0.946\right)$; outcrossing rate among relatives $\left(t_{m}-t_{s}=0.039\right)$; and selfing rate $(s=0.015)$. The multilocus correlation of selfing $\left(r_{s}\right)$ was 0.106 , multilocus paternity correlation $\left(r_{p(m)}\right)$ was 0.02 , and the effective number of pollen donors $\left(N_{e p}\right)$ was approximately 50 .

The percentage of pairwise half-sibs $\left(P_{H S}\right)$ was $95 \%$, full-sibs $\left(P_{F S}\right)$ was $1.94 \%$, and self-half-sibs $\left(P_{S H S}\right)$ was $2.96 \%$. Coancestry within progeny $(\Theta)$ was 0.131 , effective size $\left(N_{e}\right)$ was 3.75 , and number of seed trees required for seed collection $(m)$ was 40 (Table 3 ). We estimated the multilocus outcrossing $\left(t_{m}\right)$ rate based on our analysis of 20 sampled progeny (Table 4). For individual analyses, the multilocus outcrossing $\left(t_{m}\right)$ rate ranged from 0.10 to 1.00 , outcrossing rate between related individuals $\left(t_{m}-t_{s}\right)$ ranged from -0.21 to 0.14 , and the multilocus paternity correlation among progeny $\left(r_{p(m)}\right)$ was low, ranging from (0.01 to 0.1$)$. The effective number of pollen donors ranged from 10 to 100 (Table 4).

\section{Spatial genetic structure}

Only the FU population presented no significant SGS (Fig. 3a). In the PJ population, the SGS was significant up to $810 \mathrm{~m}$ with a coancestry $\left(\theta_{x y}\right)$ of 0.0211 (Fig. $3 \mathrm{~b}$ ). In the GB population, SGS was significant up to $38 \mathrm{~m}$ with a coancestry $\left(\theta_{x y}\right)$ ranging from 0.0182 to 0.0418 (Fig. 3c). In the AM population, SGS was observed up to $71 \mathrm{~m}$, with coancestry values from 0.0213 to 0.0934 (Fig. 3d).

\section{Discussion}

\section{Linkage disequilibrium, genetic diversity, fixation index, and genetic differentiation between and within populations}

The low linkage disequilibrium (3.48\%) concentrated in AM population likely does not reflect linkage between loci, but 


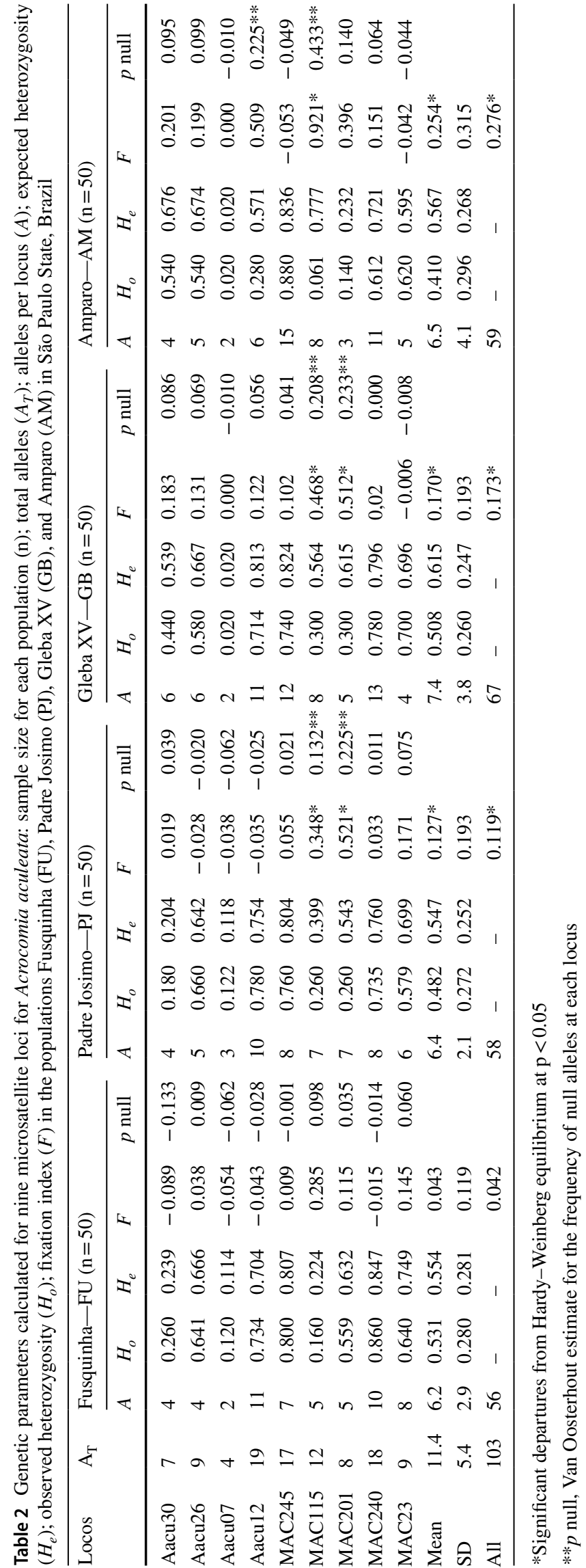


Fig. 2 Genetic structure of Acrocomia aculeata populations in São Paulo State, Brazil. a Plot based on delta-K calculated according to Evanno et al. (2005) to estimate the actual number of clusters for the 200 sampled individuals. b Assignment of $200 \mathrm{~A}$. aculeata individuals from four populations into two $(\mathrm{K}=2)$ clusters using a Bayesian-based population genetic structure analysis and the software STRUCTU RE (Pritchard et al. 2000). Each solid bar represents a single individual, while colored areas correspond to distinct genetic clusters. Bars with two colors denote admixed genomes. The populations are: Fusquinha (FU), Padre Josimo (PJ), Gleba $\mathrm{XV}$ (GB), and Amparo (AM). (Color figure online)

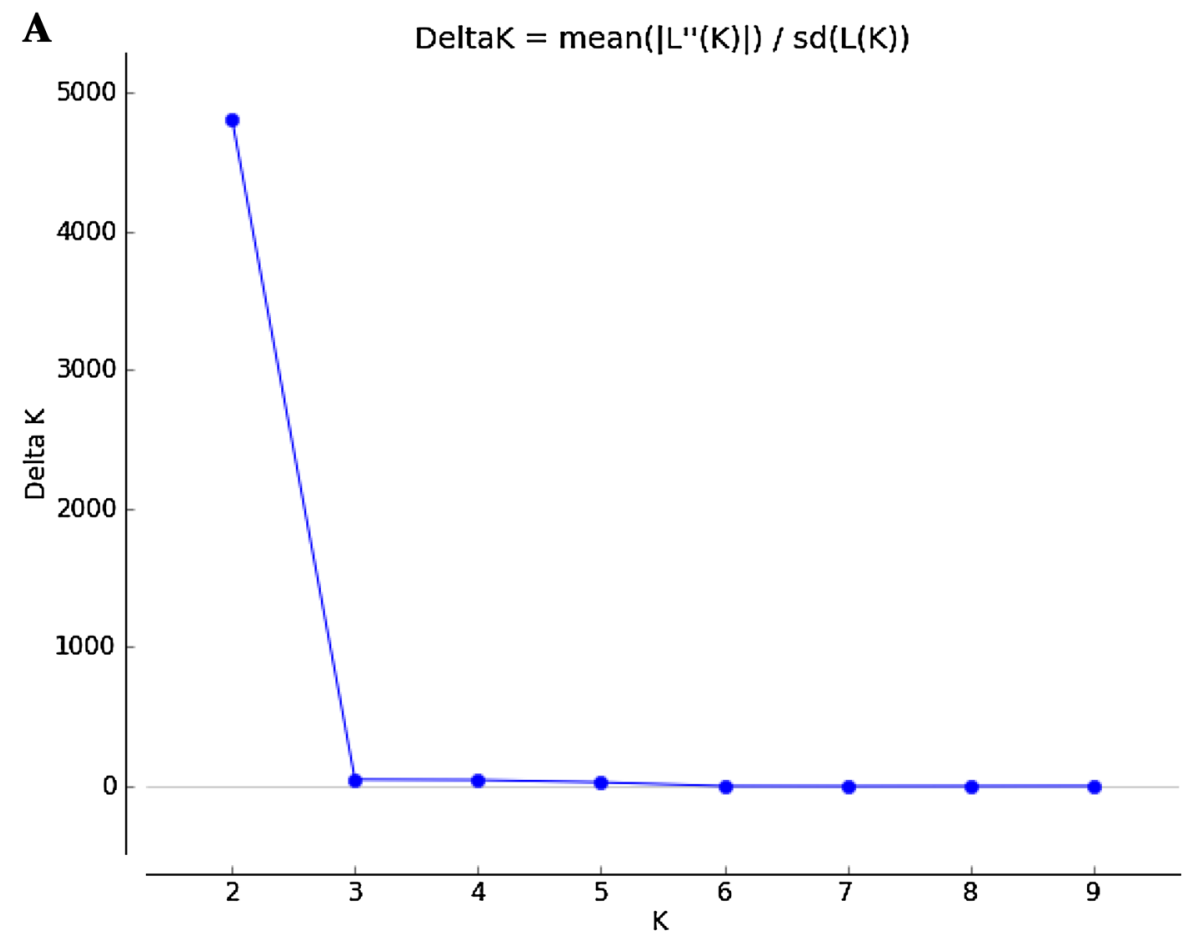

B

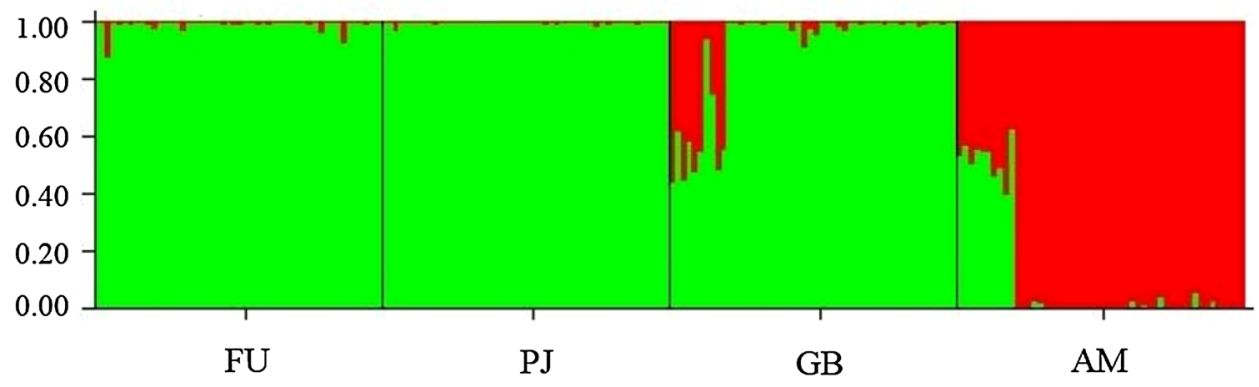

rather the influence of other factors, such as mating between related individuals, founders effect, or genetic bottlenecks. All these factors are plausible because the linkage occurs in the AM population which has the least number of individuals, occupies the smallest area (3.0 ha), and has the highest fixation index and coancestry compared to the other study populations. Similar results in tropical tree species were found by Forti et al. (2014) and Tambarussi et al. (2016) for tropical tree species. Therefore, we assume that the loci are not linked and are suitable for use in this study.

Considering the genetic diversity parameters, the studied A. aculeata populations show high levels of polymorphism. The number of alleles $(A)$ found in this study was higher than that found in other studies on the species by Nucci et al. (2008), Oliveira et al. (2012), and Lanes et al. (2016). For other palm species, such as Cocos nucifera L. (Ribeiro et al. 2010) and Euterpe edulis (Gaiotto et al. 2003), the authors found a lower average number of alleles per locus than the current study. Meanwhile, the average values of $H_{o}$ and $H_{e}$ in our study were higher than the values found by Nucci et al. (2008) and similar to those found by Lanes et al. (2016) for the same species. The results reported for $A$. aculeata by Gaiotto et al. (2003), Ribeiro et al. (2010), and Ibanes et al. (2015) were also similar to those presented herein (Table 5).

The GB and AM populations showed the greatest differences between the means of $H_{e}$ and $H_{o}(0.157$ and 0.107 , respectively), and we observed a positive and significant fixation index for the two populations (Table 2). The positive and significant fixation index $(F)$ for the means of three populations (PJ, GB, and AM) are likely biased by the presence of null alleles which results in the absence of amplification of some alleles and increases the estimates of homozygosis in populations (Pompanon et al. 2005). This deviation from the Hardy-Weinberg equilibrium is likely occurring as result of inbreeding in these populations due to gene flow via pollen and seeds. A similar result was found by Lanes et al. (2016) who reported an excess of homozygotes. 
Table 3 Mating system parameters of Acrocomia aculeata for the Fusquinha (FU) population, Pontal do Paranapanema, São Paulo State, Brazil (CI is the $95 \%$ confidence interval calculated using 1000 bootstraps)

\begin{tabular}{ll}
\hline Parameters & Average for FU (95\% CI) \\
\hline Multilocus outcrossing rate: $t_{m}$ & $0.985(0.984-0.989)$ \\
Single-locus outcrossing rate: $t_{s}$ & $0.946(0.946-0.954)$ \\
Outcrossing among relatives: $t_{m}-t_{s}$ & $0.039(0.037-0.04)$ \\
Selfing rate: $s$ & 0.015 \\
Multilocus correlation of selfing: $r_{s}$ & $0.106(0-0.106)$ \\
Multilocus paternity correlation: $r_{p_{(m)}}$ & $0.02(0.01-0.02)$ \\
Effective number of pollen donors: $N_{e p}$ & $50(48-50)$ \\
Self-sibs: $P_{S S}(\%)$ & $0(0-0.0002)$ \\
Half-sibs: $P_{H S}(\%)$ & $(95-98)$ \\
Full-sibs: $P_{F S}(\%)$ & $1.94(0.5-2)$ \\
Self-half-sibs: $P_{S H S}(\%)$ & $2.96(2.895-3.1)$ \\
Coancestry within progenies: $\Theta$ & $0.131(0.128-0.14)$ \\
Effective size: $N_{e}$ & $3.75(3.09-3.85)$ \\
Number of seed trees for seed collection: & $40(39-40)$ \\
$m$ & \\
\hline
\end{tabular}

Table 4 Mating system parameters for open-pollinated progeny arrays from Acrocomia aculeata palm trees obtained from the Fusquinha (FU) population, São Paulo State, Brazil

\begin{tabular}{lrlrlr}
\hline Progeny & \multicolumn{1}{c}{$n$} & \multicolumn{1}{l}{$t_{m} \pm \mathrm{SE}$} & $t_{m}-t_{s} \pm \mathrm{SE}$ & $r_{p(m)} \pm \mathrm{SE}$ & \multicolumn{1}{l}{$N_{e p}$} \\
\hline FU-1 & 15 & $0.94 \pm 0.01$ & $-0.02 \pm 0.01$ & $0.10 \pm 0.00$ & 10.00 \\
FU-2 & 18 & $1.00 \pm 0.00$ & $0.07 \pm 0.02$ & $0.02 \pm 0.01$ & 50.00 \\
FU-3 & 8 & $0.97 \pm 0.03$ & $0.10 \pm 0.03$ & $0.07 \pm 0.02$ & 14.29 \\
FU-4 & 15 & $0.82 \pm 0.10$ & $-0.02 \pm 0.07$ & $0.08 \pm 0.03$ & 12.50 \\
FU-5 & 6 & $0.63 \pm 0.13$ & $-0.21 \pm 0.11$ & $0.10 \pm 0.01$ & 10.00 \\
FU-6 & 10 & $1.00 \pm 0.00$ & $0.10 \pm 0.01$ & $0.04 \pm 0.02$ & 25.00 \\
FU-7 & 8 & $0.92 \pm 0.07$ & $0.04 \pm 0.06$ & $0.10 \pm 0.02$ & 10.00 \\
FU-8 & 13 & $0.91 \pm 0.07$ & $0.01 \pm 0.06$ & $0.04 \pm 0.02$ & 25.00 \\
FU-9 & 15 & $1.00 \pm 0.00$ & $0.04 \pm 0.01$ & $0.01 \pm 0.01$ & 100.00 \\
FU-10 & 11 & $0.10 \pm 0.00$ & $0.14 \pm 0.02$ & $0.07 \pm 0.02$ & 14.29 \\
FU-11 & 8 & $0.88 \pm 0.09$ & $-0.03 \pm 0.07$ & $0.08 \pm 0.02$ & 12.50 \\
FU-12 & 21 & $0.88 \pm 0.09$ & $-0.02 \pm 0.07$ & $0.02 \pm 0.02$ & 50.00 \\
FU-13 & 3 & $0.97 \pm 0.00$ & $0.06 \pm 0.01$ & $0.09 \pm 0.00$ & 11.11 \\
FU-14 & 15 & $0.92 \pm 0.07$ & $0.01 \pm 0.06$ & $0.04 \pm 0.02$ & 25.00 \\
FU-15 & 22 & $1.00 \pm 0.00$ & $0.06 \pm 0.01$ & $0.02 \pm 0.02$ & 50.00 \\
FU-16 & 19 & $1.00 \pm 0.00$ & $0.04 \pm 0.01$ & $0.02 \pm 0.02$ & 50.00 \\
FU-17 & 14 & $0.97 \pm 0.04$ & $0.04 \pm 0.04$ & $0.02 \pm 0.01$ & 50.00 \\
FU-18 & 9 & $0.89 \pm 0.09$ & $0.03 \pm 0.06$ & $0.04 \pm 0.01$ & 25.00 \\
FU-19 & 12 & $1.00 \pm 0.00$ & $0.08 \pm 0.02$ & $0.03 \pm 0.01$ & 33.33 \\
FU-20 & 21 & $1.00 \pm 0.00$ & $0.05 \pm 0.01$ & $0.03 \pm 0.03$ & 33.33 \\
\hline & & & & &
\end{tabular}

$n$-sample size; $t_{m}$-multilocus outcrossing rate; $t_{m}-t_{s}$ : rate of mating among relatives; $r_{p(m)}$-multilocus paternity correlation; $N_{e p}$ effective number of pollen donors; $\pm \mathrm{SE}-$ standard error
A

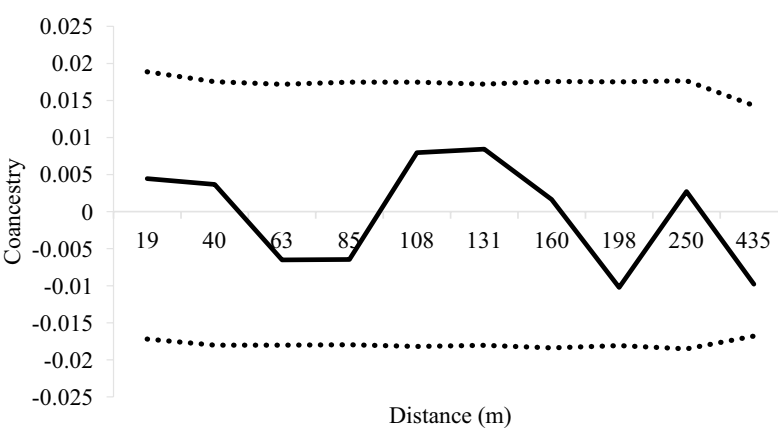

B

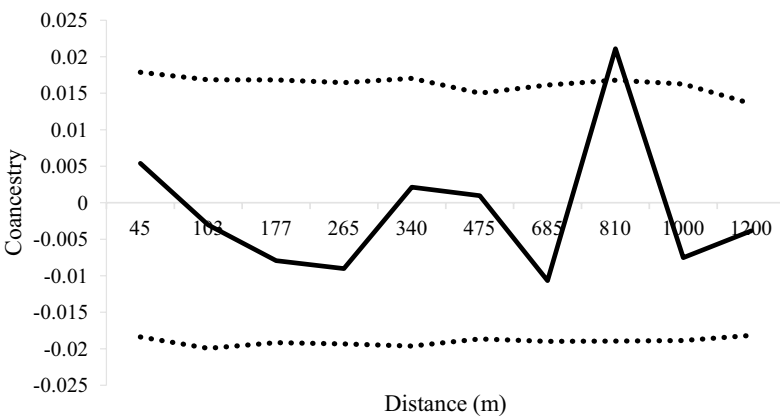

C

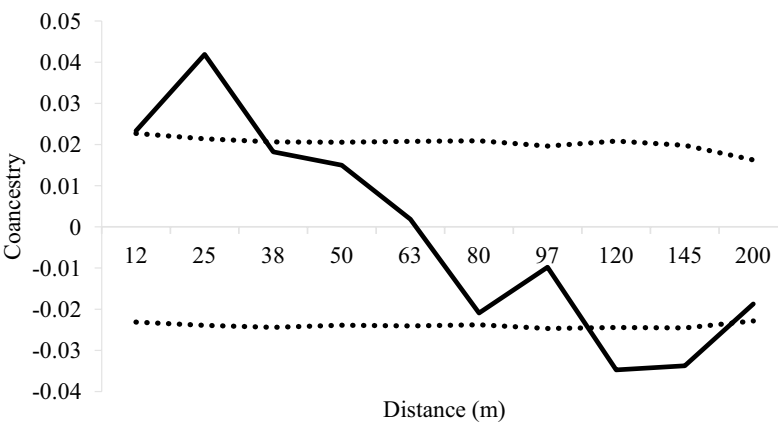

D

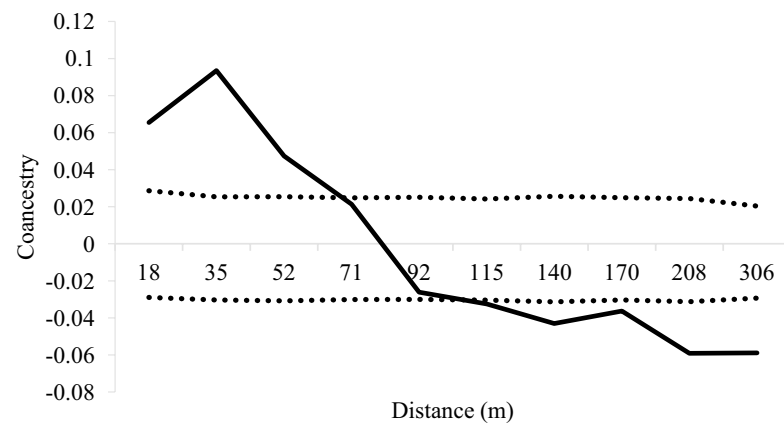

Fig. 3 Correlograms of the average coancestry coefficient $\left(\theta_{x y}\right)$ of Acrocomia aculeata from the FU (A), PJ (B), GB (C), and AM (D) populations in São Paulo State, Brazil. The solid line represents the estimate of average $\theta_{x y}$ and the dotted lines represent the two-tailed $95 \%$ confidence interval of the average $\theta_{x y}$ distribution calculated by 1000 permutations of spatial distance among pairwise adult individuals. The number of pairs of individuals range from 121 to 124 within each distance class 


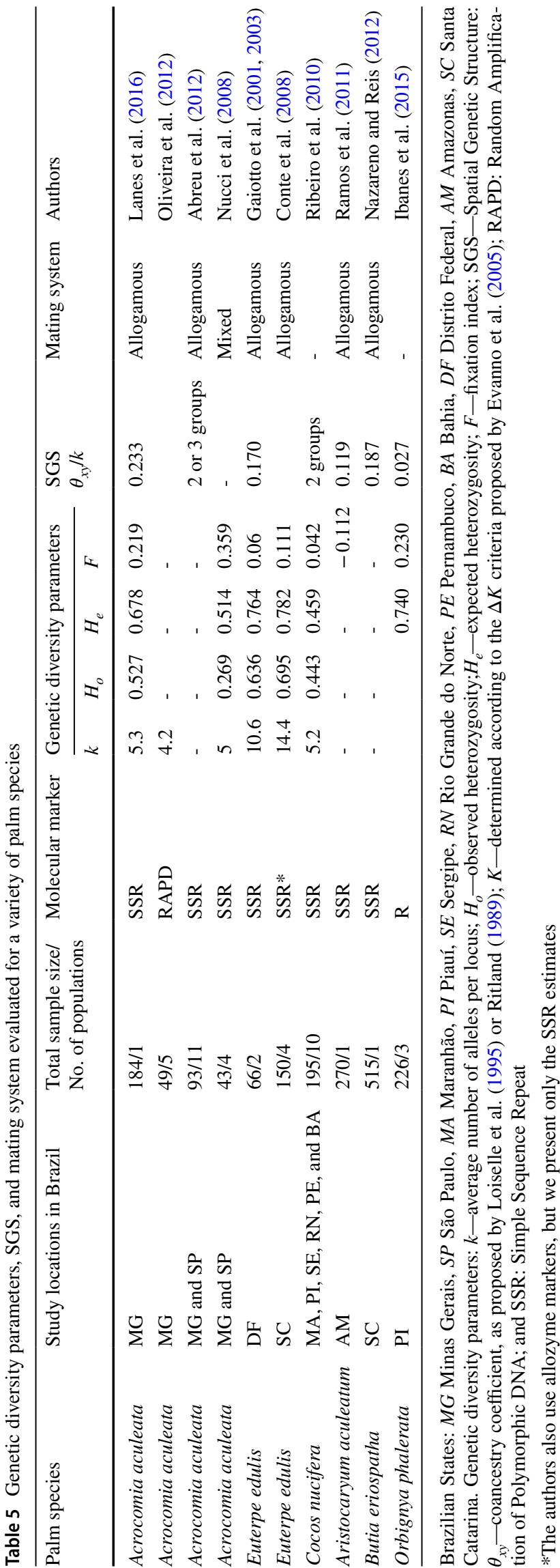

The FU population was the only population that did not present significant $F$ values. This estimate was influenced by the four loci that showed excess heterozygotes and a lack of null alleles in the population. Therefore, it is likely that the population is not suffering inbreeding and, as such, stands out as a population that can be used as a seed collection area for the production of seedlings in the region (Tambarussi et al. 2016).

Although A. aculeata has both female and male flowers in the same bunch, it is protogynous and therefore a preferentially allogamous species (Scariot et al. 1995). Nevertheless, mating between related individuals may be occurring in PJ, GB, and AM populations. Similar results were reported for Orbignya phalerata, a protogynous species studied using eight microsatellite markers and 90 adult individuals in three populations (Ibanes et al. 2015). For Astrocaryum aculeatum, Ramos et al. (2011) reported negative fixation indices and the authors attributed this result to the reproductive system of the species.

The GB population presents the most private alleles (11; 10 rare and one private), followed by AM, FU (eight in each population), and PJ (seven), suggesting that the GB population is isolated from the other Pontal do Paranapanema populations (FU and PJ) (Table 1). In the AM population, we found eight private and/or rare alleles and the absence of nine alleles that are present in the three other populations, indicating that there is no gene flow between $\mathrm{AM}$ and the other populations. AM and GB are located at greater distances and are more isolated $(605 \mathrm{~km})$ than the other study populations, suggesting that the genetic diversity parameters are affected by reproductive isolation by distance (Wright 1946). However, there are also differences between populations located in closer proximity, suggesting that even at distances of 13-30 km, gene flow does not occur. Tambarussi et al. (2015) found similar results for Cariniana legalis populations when studying large and small populations that are separated by long distances. The A. aculeata populations studied herein have a relatively high number of private alleles and an allelic diversity similar to $O$. phalerata (Ibanes et al. 2015). However, Nucci et al. (2008) found that most of the private alleles were in areas with the potential for inbreeding as they occurred in fragmented areas.

Due to evolutionary processes, such as genetic drift and natural selection, populations tend to diverge over time (Holsinger and Weir 2009). As such, we can consider that the FU and PJ populations have greater differentiation between them. The differentiation between the AM population and the other studied populations was expected due to distance and lack of gene flow. Although there is a high divergence among populations, most of the diversity is concentrated within fragments in all populations (83.2\%), a result that has been discussed for several other native species (Kageyama et al. 2003). 
The STRUCTURE analysis grouped the individuals into well-defined clusters $(1=\mathrm{FU}, \mathrm{PJ}$, and GB; $2=\mathrm{AM})$ corresponding to the two study areas. This grouping indicates that there is population structure (Pritchard et al. 2000) although there is no single pool in the studied populations. This structure may be caused by limited pollination and seed dispersal, which can contribute to differentiation. Abreu et al. (2012) suggest that because of the aggregated distribution of $A$. aculeata, pollinators tend to visit closely spaced groups of individuals, while Lanes et al. (2016) suggest that the behavior of the pollinators, which systematically visit the same inflorescence, contribute to divergence between populations.

\section{Mating system}

The outcrossing rate $\left(t_{m}\right)$ and the single locus outcrossing rate $\left(t_{s}\right)$ are high and significant in comparison with values expected for allogamous species $\left(t_{m}>0.80\right.$, based on Goodwillie et al. 2005). These values are related to pollination vectors (beetles) and the protogyny observed in the species, which facilitate cross-pollination. However, our results contradict the assertion by Scariot et al. (1991) that the species has a mixed mating system. The $r_{p_{(m)}}$ value (0.02) suggests that the probability that two crossbred individuals share the same parent is low and not significant; therefore, the studied population does not deviate from random mating (Ritland 1989). The observed percentage of half-sibs $\left(P_{H S}=95 \%\right)$ was high and percentages of self-sibs, full-sibs, and selfhalf-sibs were low ( $P_{S S}=0 \%, P_{F S}=1.94 \%$, and $\left.P_{S H S}=2.96 \%\right)$. The effective number of pollen donors $\left(N_{e p}\right)$ ranges from 10 to 100 , indicating that there are a large number of trees donating pollen and a low incidence of correlated crosses (Table 4).

The results for outcrossing among relatives $\left(t_{m}-t_{s}=0.039\right)$ suggest that mating between related individuals is uncommon in these populations. This is supported by the mean coancestry within progeny $(\Theta=0.131)$, a value similar to that expected in panmictic populations $(\Theta=0.125)$, indicating that there are low rates of mating among related individuals.

The mating system of A. aculeata was also studied by Abreu et al. (2012) with 77 seedlings from nine mother trees, divided into three populations (Amparo-AM: $n=53$; Ibiruna-IB: $n=13$; and Turvo-TR: $n=10$ ). The mean values across the studied populations reported by the authors $\left(t_{m}=0.65 ; t_{s}=0.44 ; t_{m}-t_{s}=0.21 ;\right.$ and $\left.r_{p_{(m)}}=0.29\right)$ suggest that the species has a mixed mating system. Lanes et al. (2016) also studied the mating system of this species by sampling 19 mother trees located in natural populations from southeastern Brazil and 157 juveniles located at "Macauba Active Germplasm Bank" in Minas Gerais State. Their results showed a multilocus outcrossing rate of 0.986 , single-locus outcrossing rate of 0.603 , outcrossing among relatives of 0.383 , and multilocus paternity correlation of 0.564 . Thus, we can conclude that the mating system of $A$. aculeata is predominantly outcrossing with individual variation for self-incompatibility which may be a survival strategy in isolated or fragmented habitats and can vary between and within populations.

The results discussed by Abreu et al. (2012) were different from those found in the present study. First, the authors note that estimating outcrossing rates using established seedlings may bias the results due to inbreeding depression that can occur between seed development and seedling establishment (Abreu et al. 2012). Second, the mean $t_{m}$ is much lower than the results found for two of the three populations: IB and TR $\left(\hat{t}_{m}=1.0\right)$. This could be influenced by the sample size $(n=77)$ and strategy, which included a greater number of individuals from the population with a lower multilocus outcrossing rate (AM: $n=57, \hat{t}_{m}=0.73$ ) than the populations with a higher multilocus outcrossing rate (IB: $n=13$ and TR: $n=10$ and $\hat{t}_{m}=1.0$ ).

Another reason for the differences between these two studies is that the mating system may be influenced by environmental factors that can affect the foraging behavior of pollinators (Eckert et al. 2010). According to Sebbenn (2006) and Tambarussi et al. (2016), the rate of crossing between plants can vary widely among populations, between reproductive events of the same population, and even between flowers on the same tree. We must consider that crossings between relatives is associated with the SGS of a population (Ritland and Jain 1981; Moraes et al. 2004). In our analysis of genetic diversity, the population used herein (FU population) did not present significant fixation index and was the only population that did not present significant SGS, which could explain the low rate of crossing between relatives. The AM population studied by Abreu et al. (2012) is the same AM population used herein (Table 4) and the results show a significant fixation index, which may also be associated with the low multilocus outcrossing rate found by the authors.

For other palm species, such as E. edulis (Gaiotto et al. 2003; Conte et al. 2008), the analysis of the mating system suggests that the species is allogamous. In both previous studies, the results showed mating between relatives and biparental inbreeding. In these cases, the authors argue that the phenology of the species favors the occurrence of nonrandom mating. For progenies of A. aculeatum, Ramos et al. (2011) reported that the species is allogamous with a low rate of mating between relatives and low correlation between crosses. For Butia eriospatha, Nazareno and Reis (2012) argue that the species is predominately outcrossing with a certain level of mating between related individuals and a high level of parental correlation, demonstrating that mating for this palm is not random. 
In the present study, the $N_{e}=3.75$ was high and similar to the expected maximum for panmictic populations $\left(N_{e} \approx 4\right)$. This difference among the expected and observed $\left(N_{e}\right)$ can be due to the occurrence of mating between relatives. Considering a reference effective size $\left(N_{e}=150\right)$ for short-term conservation, the number of seed trees necessary for seed collection in the study region is 40 .

\section{Spatial genetic structure}

SGS is influenced by mating system, gene flow, population density caused by the dispersal of seeds and pollen near to the mother tree, and overlapping generations (Sebbenn et al. 2011; Silva et al. 2011). As A. aculeata is pollinated by beetles and small bees that tend to have short flight distances, there is likely limited gene flow across these populations. Meanwhile, seeds are dispersed primarily by barochory and secondarily by large animals, such as Tapirus terrestris (Pott and Pott 1994; Scariot 1998), a threatened species due to habitat loss, illegal hunting, and competition with livestock (Naveda et al. 2008).

Our results show that only the FU population presents no significant SGS (Fig. 3a), suggesting that in this population, pollinators and seed dispersers can be effective in promoting gene flow and avoiding the structuring of populations. This result is likely related to the lower number of rural families living in the area; therefore, the subsistence activities (farming and livestock) of these families may not affect the $A$. aculeata population. Furthermore, the population has a high density of individuals per hectare (average 300 palms ha $^{-1}$ ) which can support the presence of seed dispersers. As such, the FU population can be included in seed collection programs since individuals are unlikely to be correlated, even if they do occur within short distances. The FU population also showed no null alleles and significant fixation index $(F)$, which supports the result of an absence of coancestry found through the analysis of SGS. In PJ, the occurrence of SGS in distance classes longer than the other populations $(810 \mathrm{~m})$ may indicate that large dispersers are present and may be carrying the seeds further away from the mother tree, which may also be occurring in the FU population (Fig. 3b). Similar to the FU population, the rural families settled in PJ may not inhibit the presence of seed dispersers (Pott and Pott 1994; Ibanes et al. 2015).

In the GB and AM populations, we found significant SGS (Fig. 3c, d), suggesting that palm trees occurring within certain distances may be related. In GB, the SGS indicates that individuals up to $38 \mathrm{~m}$ are second cousins $\left(\theta_{x y}=0.03125\right)$ and can be the result of short distance pollination in a small population and the absence of seed dispersers. In the AM population, SGS was observed up to $71 \mathrm{~m}$ with values similar to first cousins $\left(\theta_{x y}=0.0625\right)$ (Lindgren et al. 1997) and half-sibs $\left(\theta_{x y}=0.125\right)$ (Weir and Cockerham 1984). This result can be explained by the degree of isolation of this population and the levels of inbreeding, as indicated by the fixation index. The shorter distances of SGS may be related to an absence of long distance seed dispersers and short distance pollen flow. Similar results were found for $O$. phalerata, a palm pollinated by beetles and wind, and dispersed by barochory and rodents, in which SGS occurs from 40 to $60 \mathrm{~m} \mathrm{(} \theta_{x y}=0.0217$ to 0.0345 ; Ibanes et al. 2015).

The coancestry observed for the FU and PJ populations are relatively low compared to the coancestry found for the GB and AM populations, which is consistent with the fixation index for these two populations. The AM and GB populations are more disturbed environments than the others due to their size and isolation. The AM population is located in a small area (approximately $3.0 \mathrm{ha}$ ) adjacent to an urban area and GB is a fragment within one of the main settlements of Pontal do Paranapanema.

According to Nucci et al. (2008), the genetic structure of A. aculeata can be explained by the degree of anthropogenic disturbance in the study region, which results in a reduction in genetic variability and gene flow among populations and changes the foraging behavior of pollinators (Eckert et al. 2010), as mentioned above.

\section{Conclusions and recommendations for conservation}

An increased understanding of genetic diversity among and within natural populations can contribute to the conservation of protected areas and regional development. Our results show that the species studied herein has a high genetic diversity in the Pontal do Paranapanema region. As with most tropical, outcrossing, wind pollinated species, and similar to most of the arboreal forest taxa in the Northern Hemisphere, the majority of the species diversity is concentrated within populations. A. aculeata is allogamous, presents low levels of mating between related individuals and does not present significant paternity correlation. In the Pontal do Paranapanema region, the Fusquinha (FU) population showed a non-significant fixation index and an absence of SGS. Thus, FU population could be managed as a sustainable resource and could be used as sources for seed collection programs. The Gleba XV (GB) and Amparo (AM) populations have short distance SGS and inbreeding may be occurring in both. Therefore, we recommend harvesting seeds from seed trees located at distances of at least 38 and $71 \mathrm{~m}$, respectively, to avoid collecting seeds from related individuals in these populations. In order to reach the $N_{e(r e f)}$ of 150 , at least 40 palm trees should be included in seed collection strategies to maintain high levels of genetic diversity. 
Acknowledgements We thank the Laboratório de Reprodução e Genética de Espécies Arbóreas (LARGEA, ESALQ/USP) for providing the physical support necessary to complete this work. We thank Lya Carolina da Silva Mariano Pereira and Marcelo Nalin Ambrosano for laboratory support, Jefferson Polizel for developing the maps, and Dario Grattapaglia for providing the unpublished loci. We also acknowledge the assistance of Prof. Dr. Paulo Kageyama (in memorian). This study was funded by the Fundação de Amparo à Pesquisa do Estado de São Paulo (FAPESP-2013/23168-4). Natalia Coelho was supported by a CAPES Master's Degree scholarship.

\section{References}

Abreu AG, Priolli RHG, Azevedo-Filho JA, Nucci SM, Zucchi MI, Coelho RM, Colombo CA (2012) The genetic structure and mating system of Acrocomia aculeata (Arecaceae). Genet Mol Biol 35:116-121. https://doi.org/10.1590/S1415-47572012005000002

Charlesworth B, Charlesworth D (1999) The genetic basis of inbreeding depression. Genet Res Camb 74:329-340

Conte R, Mantovani A, Reis MS, Venkovsky R (2008) Genetic structure and mating system of Euterpe edulis Mart. populations: a comparative analysis using microsatellite and aloenzyme markers. J Hered 99:476-482. https://doi.org/10.1093/jhered/esn055

Ditt EH (2002) Fragmentos florestais no Pontal do Paranapanema. Annablume, São Paulo

Doyle JJ, Doyle JL (1990) Isolation of plant DNA from fresh tissue. Focus 12:13-15

Eckert CG, Kalisz S, Geber MA, Sargent R, Elle E, Cheptou PO, Goodwillie C, Johnston MO, Kelly JK, Moeller DA, Porcher E, Ree RH, Vallejo-Marin M, Winn AA (2010) Plant mating system in a changing world. Trends Ecol Evol 25:35-43. https://doi. org/10.1016/j.tree.2009.06.013

Evanno G, Regnaut S, Goudet J (2005) Detecting the number of clusters of individuals using the software STRUCTURE: a simulation study. Mol Ecol 14:2611-2620. https://doi.org/10.1111/j.1365294X.2005.02553.x

Forti G, Tambarussi EV, Kageyama PY, Moreno MA, Ferraz EM, Ibanes B, Mori GM, Vencovsky R, Sebbenn AM (2014) Low genetic diversity and intrapopulation spatial genetic structure of the Atlantic Forest tree, Esenbeckia leiocarpa Engl. (Rutaceae). Ann For Res 57:165-174. https://doi.org/10.15287/afr.2014.226

Gaiotto FA, Grattaplaglia D, Vencovsky R (2001) Microssatelite markers of heart of palm- Euterpe edulis and E. oleraceae Mart. (Arecaceae). Mol Ecol 1:86-88. https://doi.org/10.104 6/j.1471-8278.2001.00036.x

Gaiotto FA, Grattaplaglia D, Vencovsky R (2003) Genetic structure, mating system, and long-distance gene flow in Heart of palm (Euterpe edulis Mart.). J Hered 94:399-406. https://doi. org/10.1093/jhered/esg087

Goodwillie C, Kalisz S, Eckert CG (2005) The evolutionary enigma of mixed mating system in plants: occurrence, theoretical explanations, and empiric evidence. Annu Rev Ecol Syst 36:47-79. https ://doi.org/10.1146/annurev.ecolsys.36.091704.175539

Goudet J (2001) FSTAT, a Program to Estimate and Test Gene Diversities and Fixation Indices, Version 2.9.3. http://www.unil.ch/izea/ softwares/fstat.html. Accessed 1 Jan 2015

Hardy OJ, Vekemans X (2002) Spagedi: a versatile computer program to analyse spatial genetic structure at the individual or population levels. Mol Ecol Notes 2:618-620. https://doi.org/10.104 6/j.1471-8286.2002.00305.x

Holsinger KE, Weir BS (2009) Genetics in geographically structured populations: defining, estimating and interpreting $\mathrm{F}_{\mathrm{ST}}$. Nat Rev Genet 10:639-650. https://doi.org/10.1038/nrg2611
Ibanes B, Sebbenn AM, Azevedo VCR, Moreno MA, Gandara FB, Tambarussi EV, Ferraz EM, Damasceno-Silva KJ, Lima PSC, Carvalhaes MA (2015) Genetic diversity and spatial genetic structure in population of Orbignya phalerata Mart. under different exploitation intensities in the Brazilian savanna. Silvae Genet 64:201-211. https://doi.org/10.1515/sg-2015-0019

Instituto De Pesquisas Espaciais (2015) Atlas dos Remanescentes Florestais da Mata Atlântica. http://mapas.sosma.org.br/site media/download/atlas_2013-2014_relatorio_tecnico_2015.pdf. Accessed 2 Sept 2017

Kageyama PY, Gandara FB, Oliveira RE (2003) Biodiversidade e restauração da Floresta Tropical. In: Kageyama PY, Oliveira RE, Morais LFD, Engel VL, Gandara FB (eds) Restauração Ecológica de Ecossistemas Naturais. FEPAF, Botucatu, pp 27-48

Lacerda AEB, Kanashiro M, Sebbenn AM (2008) Long-pollen movement and deviation of random mating in a low-density continuous population of a tropical tree Hymenaea courbaril in the Brazilian Amazon. Biotropica 40:462-470. https://doi.org/10.111 1/j.1744-7429.2008.00402.x

Lander TA, Boshier DH, Harris SA (2010) Fragmented but not isolated: contribution of single trees, small patches and long-distance pollen flow to genetic connectivity for Gomortega keule, an endangered Chilean tree. Biol Conserv 143:2583-2590. https ://doi.org/10.1016/j.biocon.2010.06.028

Lanes ECM, Motoike SY, Kuki KN, Resende MDV, Caixeta ET (2016) Mating system and genetic composition of the macaw palm (Acrocomia aculeata): implications for breeding and genetic conservation programs. J Hered 107:527-536. https://doi.org/10.1093/ jhered/esw038

Leite JF (1999) A ocupação do Pontal do Paranapanema. Hucitec, São Paulo

Leitman P, Soares K, Henderson A, Noblick L, Martins RC (2015) Arecaceae, in: Lista de Espécies da Flora do Brasil. Jardim Botânico do Rio de Janeiro. Available at http://floradobrasil.jbrj.gov.br/ jabot/floradobrasil/FB15663. Accessed 26 June 2015

Lindgren D, Gea LD, Jefferson PA (1997) Status number for measuring genetic diversity. Forest Res 4:69-76

Loiselle BA, Sork VL, Nason J, Graham C (1995) Spatial genetic structure of a tropical understory shrub, Psychotria officinalis (Rubiaceae). Am J Bot 82:1420-1425. https://doi.org/10.2307/2445869

Moraes MLT, Kageyama PY, Sebbenn AM (2004) Correlated mating in dioecious tropical tree species. Myracrodruon urundeuva $\mathrm{Fr}$ All For Genet 11:53-59

Murashige T, Skoog F (1962) A revised medium for rapid growth and bioassays with tobacco tissue cultures. Physiol Plantarum 15:473-497. https://doi.org/10.1111/j.1399-3054.1962.tb08052.x

Naveda A, de Thoisy B, Richard-Hansen C, Torres DA, Salas L, Wallance R, Chalukian S, de Bustos S (2008) Tapirus terrestres. IUCN Red List Threat Species 2008:T21474A9285933. https:// doi.org/10.2305/IUCN.UK.2008.RLTS.T21474A9285933.en

Nazareno AG, Reis MS (2012) Linking phenology to mating system: exploring the reproductive biology of the threatened palm species Butia eriospatha. J Hered 103:842-852. https://doi.org/10.5061/ dryad.d2pd6

Nucci SM, Azevedo-Filho JA, Colombo CA, Priolli RHG, Coelho RM, Mata TL, Zucchi MI (2008) Development and characterization of microsatellites markers from the macaw. Mol Ecol Res 8:224-226. https://doi.org/10.1111/j.1471-8286.2007.01932.x

Oliveira DA, Melo Júnior AF, Brandão MM, Rodrigues LA, Menezes EV, Ferreira PRB (2012) Genetic diversity in populations of Acrocomia aculeata (Arecaceae) in the northern region of Minas Gerais, Brazil. Genet Mol Res 11:531-538. https://doi. org/10.4238/2012.March.8.1 
Pompanon F, Bonin A, Belleman E, Taberlet P (2005) Genotyping errors: causes, consequences and solutions. Nat Rev Genet 6:847859. https://doi.org/10.1038/nrg 1707

Pott A, Pott VJ (1994) Plantas do pantanal. Embrapa, Brasília

Pritchard JK, Stephens M, Donnelly P (2000) Inference of population structure using multilocus genotype data. Genetics 155:945-959

Ramos SLFR., Lopes MTG, Lopes R et al (2011) Determination of the mating system of Tucumã palm using microsatellite markers. Crop Breed Appl Biot 11:181-185. https://doi.org/10.1590/S1984 $-70332011000200011$

Ribeiro FR, Baudouin L, Lebrun P, Chaves LJ, Brondani C, Zucchi MI, Venkovsky R (2010) Population structures of Brazilian tall coconut (Cocos nucifera L.) by microsatellite markers. Genet Mol Biol 33:696-702. https://doi.org/10.1590/S1415-47572010005000077

Ribeiro LM, Souza PP, Rodrigues JR, Oliveira TGS, Garcia QS (2011) Overcoming dormancy in macaw palm diaspores, a tropical species with potential for use as bio-fuel. Seed Sci Technol 39:303312. https://doi.org/10.15258/sst.2011.39.2.04

Ritland K (1989) Correlated-matings in the partial selfer, Mimulus guttatus. Evolution 43:848-859. https://doi. org/10.1111/j.1558-5646.1989.tb05182.x

Ritland K (2002) Extensions of models for the estimation of mating systems using $\mathrm{n}$ independent loci. Heredity 88:221-228. https:// doi.org/10.1038/sj.hdy. 6800029

Ritland K, Jain S (1981) A model for the estimation of outcrossing rate and gene frequencies using in independent loci. Heredity 47:35-52. https://doi.org/10.1038/hdy.1981.57

Scariot AO (1998) Seed dispersal and predation of the palm. Acrocomia aculeata Principes 42:5-8

Scariot AO, Lleras E, Hay JD (1991) Reproductive biology of the Palm Acrocmia aculeate in Central Brazil. Biotropica 23:12-22. https:// doi.org/10.2307/2388683

Scariot AO, Lleras E, Hay JD (1995) Flowering and fruiting phenologies of the palm Acrocomia aculeata: patterns and consequences. Biotropica 27:168-173

Sebbenn AM (2003) Tamanho amostral para conservacão ex situ de espécies arbóreas com sistema misto de reprodução. Rer Inst Flor $15: 109-124$

Sebbenn AM (2006) Sistema de Reprodução em espécies arbóreas tropicais e suas implicações para a seleção de árvores matrizes para reflorestamento ambientais. In: Silva LD, Higa AR (eds) Pomar de sementes de espécies florestais nativas. FUPEF, Curitiba, pp 93-138

Sebbenn AM, Carvalho ACM, Freitas MLM, Moraes SMB, Gaino APSC., Silva JM, Jolivet C, Moraes MLT (2011) Low levels of realized seed and pollen gene flow and strong spatial genetic structure in a small, isolated and fragmented population of the tropical tree Copaifera langsdorffii Desf. Heredity 106:134-145. https:// doi.org/10.1038/hdy.2010.33

Silva MS, Vieira FA, Carvalho D (2011) Diversity and genetic structure in natural populations of Genoma schottiana Mart. (Arecaceae): implications for conservation. Cerne 17:195-2001. https://doi. org/10.1590/S0104-77602011000200006

Silva PHM, Shepherd M, Grattapaglia D, Sebbenn AM (2016) Use of genetic markers to build a new generation of Eucalyptus pilularis breeding population. Silvae Genetica 64:170-181. https://doi. org/10.1515/sg-2015-0016

Sistema de Informações Florestais do Estado de São Paulo-SIFESP (2009) Quantificação da Vegetação Natural Remanescente para Bacias Hidrográficas do Estado de São Paulo. http://www.iflor estal.sp.gov.br/sifesp/tabelas/bacia_inve2010.pdf. Accessed 28 Sept 2013

Tambarussi EV, Boshier D, Vencovsky R, Freitas MLM, Sebbenn AM (2015) Paternity analysis reveals significant isolation and near neighbour pollen dispersal in small Cariniana legalis Mart. Kuntze populations in the Brazilian Atlantic Forest. Ecol Evol 5:4735-5147. https://doi.org/10.1002/ece3.1816

Tambarussi EV, Boshier D, Vencovsky R, Freitas MLM, Di-Dio OJ, Sebbenn AM (2016) Several small: how inbreeding affects conservation of Cariniana legalis Mart. Kuntze (Lecythidaceae) the Brazilian Atlantic Forest's largest tree. Int Forest Rev 18:502-510. https://doi.org/10.1505/146554816820127550

Tambarussi EV, Boshier D, Vencovsky R, Freitas MLM, Sebbenn AM (2017) Inbreeding depression from selfing and mating between relatives in the Neotropical tree Cariniana legalis Mart. Kuntze. Conserv Genet 18:225-234. https://doi.org/10.1007/s1059 2-016-0896-4

Van Oosterhout C, Weetman D, Hutchinson WF (2006) Estimation and adjustment of microsatellite null alleles in nonequilibrium populations. Mol Ecol Notes 4:535-538. https://doi.org/10.111 1/j.1471-8286.2004.00684.x

Weir BS, Cockerham C (1984) Estimating F-statistics for the analysis of population structure. Evolution 38:1358-1370. https://doi. org/10.2307/2408641

Wright $S$ (1946) Isolation by distance under diverse systems of mating. Genetics 31:39-45

Wright S (1951) The genetical structure of populations. Ann Eugen 15:313-354 